\title{
The Ethnomental Components of F.M. Dostoevsky's Works
}

\author{
Maksim Proskuriakov ${ }^{1}$ Li Lanlan ${ }^{2}$ \\ ${ }^{1,2}$ Shandong University, School of Foreign Languages and Literature, China
}

\begin{abstract}
Purpose of the study: The purpose of the study is to identify the originality and ideological functional status of the ethnomental component in the works of F. Dostoevsky.

Methods: The work integrates a complex of modern approaches and methods, mainly focusing on the ideas and principles of the traditional, cultural and historical method, which demonstrates the general cultural, sociological, and psychological aspects of the study of Dostoevsky's literary heritage. The typological method has contributed to the literary clarification of the ethnomental components in fiction and journalism of the writer. The narratological approach is used to analyze the narrative structure of Dostoevsky's works, the correlation of the writer's and other people's speech, to identify various points of views on the problem, and to establish the ambiguity of the writer's position. The contextual analysis allowed analyzing the images of characters, first, within the local context and, second, within the macrocontext, which includes other literary sources, appropriate comparisons and build a verification model of the study.

Main results: The analysis of the writer's life, his philosophy of life, sacrifices, social ambivalence, predisposition to reflection, etc. suggests the presence of certain mental foundations. The main ideas, attitudes, spiritual discoveries of the artistic worlds created by the writer are determined by the ethnomental basis of his worldview. This makes it possible to determine and understand the originality and uniqueness of Dostoevsky in the context of Russian literature.

Application of the study: The conclusions of the study can serve as the basis for an accurate idea of the correlation of the writer's worldview and his work. The materials and conclusions of the study can be used in university courses on the history of Russian literature, in special courses and special seminars on the works of Dostoevsky, for term papers, graduation papers, and dissertations.

The scientific novelty of the study lies in the fact that the ethnic component in the ideological and artistic system of Dostoevsky who was a Pochvennik writer (i. e. belonged to the Pochvennichestvo movement) was first considered in the context and through the prism of both the life experience of the writer himself and the general anthropological orientation of the writer as well as his understanding of human nature. This study provides not only the opportunity to analyze the ethnic identity of Russian literature but also to trace the influence of the ethnic mentality of Dostoevsky on his worldview embodied in his fiction.
\end{abstract}

Key words: Orthodoxy, religious devotedness, archetype, anthropocentrism, fantastic realism, mythologeme.

\section{Introduction}

The global literary process is represented by the best examples of national literature the value of which lies not only in the highest spiritual achievements of the universal character but also in clarifying the individuality and uniqueness of ethnic existence. This uniqueness reveals the full diversity of the human character (Razzhivin et al., 2019; Shafazhinskaya et al., 2019b; Khazankovich, 2019). It would not be an exaggeration to say that the Russian writer of the 19th century F.M. Dostoevsky (1821-1881) belongs to the most prominent representatives of fiction writers of all time.

(c) AesthetixMS 2020. This Open Access article is published under a Creative Commons Attribution Non-Commercial 4.0 International License (http://creativecommons.org/licenses/by-nc/4.o/), which permits non-commercial re-use, distribution, and reproduction in any medium, provided the original work is properly cited. For citation use the DOI. For commercial re-use, please contact editor@rupkatha.com. 
Without the author of "The Brothers Karamazov", it would not be possible to imagine the history of worldly elegant prose, especially when it comes to the era of art nouveau.

The works of Dostoevsky belong to the summit phenomena of world literature. His novels became a kind of art laboratory where he ran a deep study of the human spiritual world and tested the main social, moral, and philosophical ideas that reflect on the spiritual life of humanity over the past one and a half centuries. He worked during the revival and formation of the Russian nation, the development of literature, and the emergence of independent philosophical thought. The writer's work is marked by a penetrating look into human nature and a prophetic meaning, thereby going beyond the Russian context without losing its relevance. His works, which became a shock, a big discovery, a kind of revelation for the Russian and European audience of the second half of the 19th century (Shchennikov, 2001), remain very influential, as evidenced, in particular, by a number of their adaptations in the 2oth and already in the new, 21st century (Wang, 2018).

The fact that the triumph of Dostoevsky's works continues at the beginning of the 21st century is evidenced by the results of a survey conducted in the spring of 2002 by book clubs in Norway. The survey was conducted among 100 writers from 54 countries from all over the world. Each of the respondents-and among them, there were many Nobel laureates in the field of literature, which added solidity and credibility to the survey-had to name the ten works of world literature that were the best in their opinion. Based on their answers, the organizers drew up a list of one hundred favorite texts, that is, the one most often mentioned in the survey. It was a list of the most valuable and influential works of fiction of the past and the present. In terms of the number of works that fell into the elite hundred, Dostoevsky won the first place. The respondents recognized four of his novels (Crime and Punishment, The Idiot, Demons, The Brothers Karamazov) as worthy of belonging to the Library of World Literature (Sontag, 2007). Despite the simplified nature of this approach (it may not be entirely correct to measure the value of literary works by such criteria as the number of references, citation frequency, rankings, some other quantitative indicators), the fact that in the above survey Dostoevsky outperformed even William Shakespeare whose plays have been highly valued for all times, says much.

The works of Dostoevsky strike the reader by the consistent Orthodox worldview and the depth of the "Russian soul", which is didactically embodied in the writer's texts, the entry into which always causes a lot of sensations and thoughts. First of all, the reader seems to be in a state of disorientation from intriguing and complicated plot labyrinths, attracted to dualistic-opposition images and polysemantic symbols, the key to the understanding of which should be sought in the Bible, folklore, and literature of previous eras (Karasev, 1994). In the texts of Dostoevsky, one can notice seemingly incongruous elements, such as criminal stories and the lives of saints, a psychological breakdown, and apocryphal legends, an adventurous plot and a sermon, melodramatic nature and naturalism, philosophical thoughts and pastoral teachings. Behind all this, comes the real spiritual depth of the individual, a real attitude towards God, real ideas that the characters live with (Rev. Iustin (Popovich), 2007).

Thus, Dostoevsky's novels, reach far beyond the scope of literary studies, being a very productive source both for interpreting important, "eternal" philosophical problems and for interpreting the urgent problems of the present, both on the social and individual level. According to research (Okladnikova, 2006), an analysis of the national features of various kinds of literature leads to a better understanding of their distinctive features and allows tracing the development of world literature in the context of the past and the present. Clarification of the typological ethnic characteristics of-the leading Russian writers, namely Dostoevsky, is not just relevant, but necessary. The mentality of an ethnos is a phenomenon that cannot be represented as purely mental or 
psychological traits, as they are inalienable from the forms of social life which not only determine the emergence of such traits, but also serve as the basis for their constant reproduction, and are also inalienable from the world of symbolic cultural forms and the meanings in which these traits are reproduced. Mentality exists inseparably from the historical and cultural being of an ethnos, which (being) creates and reproduces a certain "model" of the personality type desired for it (Gubanov, 2014).

In our context, the concept of "mindset" is used to arrange aspectual or partial manifestations of mentality. "The mindset of the nation is at the same time the mentality of its representatives. It is rooted in the subconscious depths of the human psyche.... The mindset reflects the specific features of the corresponding type of culture ... it determines the behavior of a person, a social group, a society" (Dumnova, 2013, p. 26). Thus, in real life, we usually deal with a mentality that is the reflection of the collective in the individual. Moreover, the sources of both mentality and mindset are conditioned by the same circumstances, either the peculiarities of a person's worldview or the way of thinking following their civilizational affiliation. One of the first scholars who introduced the term "mindset" into the academic discussion is the French psychologist L. LévyBruhl in his work "How Natives Think" (Les fonctions mentales dans les sociétés inférieures) (1910). Subsequently, E. Durkheim used this term in the work The Elementary Forms of the Religious Life (Les formes élémentaires de la vie religieuse) (1912) where he writes: "The mental state of society is nothing but a collective representation" (Durkheim, 1996, p. 226). The famous Spanish philosopher J. Ortega y Gasset connects the formation of the mindset of any ethnicity with its lifestyle, which "is the starting point for any further discussion" (Ortega y Gasset, 1991, p. 402).

All Russian scholars adhere to common views regarding the genesis and specifics of the Russian mentality. According to researchers, the mentality in its ethnic dimension is objectively mediated by a whole complex of factors (geo-climatic (topography, climate, geographical location, etc.), ethnohistorical (community of historical conflicts and changes), socio-economic (domination of certain social institutions in society for a long time), religious (the formation of a hierarchy of values based on religious dogmas and under the control of religious institutions), political (the influence of the political regime), etc) (Eromasova \& Kutbiddinova, 2010). E.V. Kuznetsova understands ethnicity as "a special style of world perception, a style of thinking and behavior that is inherent only to this ethnos. Mentality, thinking, and stereotypes of behavior distinguish one ethnos from another" (Kuznetsova, 2008, p. 125). Mentality makes it possible to discover the "secret of ethnicity", which consists, first of all, in the-way of understanding things, which is consolidated by the whole legacy of ethnic culture, and which reproduces ethnic ideas about the level of development of this community, about the positive qualities and shortcomings, the basic elements of spiritual life, the place of traditions and innovation.

Considering the mindset of the Russian people, A.P. Butenko (2004), in particular, identifies the following main features: compassion (the influence of the Orthodox tradition), the predominance of morality over law and politics, community and collegiality. E.I. Zinovieva includes the following traits in the mental characteristics of Russians: hospitality, a high level of sexual morality, sociability, attachment to traditions, love for children, static family relationships, the desire to live a spiritual life, deep respect for ancestors, courage, respect for the woman as a mother. Along with these features, E.I. Zinovieva (2010) also mentions mutual misunderstanding, quarrels, uncertainty, and impulsivity. N.A. Berdyaev (1997) wrote that an invariable feature of the Russian mentality was its inconsistency, antinomy, dichotomy, which, first of all, manifested itself concerning the state (desire for "freedom from the state" vs "huge and powerful statehood), nationalism (lack of chauvinism and aggressive nationalism vs national bragging and conceit). D. Likhachev wrote about the inconsistency of the Russian mindset in his work "Thoughts about 
Russia". In his opinion, in the Russian national mindset "not only different traits are crossed, but these are traits in a "single register": religiosity combined with extreme godlessness, selflessness with greed for profit, practicalism with complete helplessness in front of external circumstances, national self-spitting with high self-conceit" (Likhachev, 2004, p. 221).

Thus, the study of the ethnic component of the work of the Russian writer and philosopher Dostoevsky will provide an opportunity to clarify deeply the discovery that this writer has made in the field of the human spirit. The need to study the work of Dostoevsky is also conditioned by the fact that the work of the latter, some of his philosophical ideas and understanding of human existence are characteristic of Russian literature.

\section{Literature Review}

The issue of analysis of various aspects of Dostoevsky's work has been repeatedly raised in literary criticism. A considerable amount of Russian and foreign research is devoted to the studies reviewing works of Dostoevsky. Dostoevsky's world was discovered in the "Silver Age" of Russian literature when the novelty of the writer's artistic view on the human being was first emphasized. In his 1893 book On the causes of decline and the new trends of modern Russian literature D.S. Merezhkovsky drew attention to the fact that Raskolnikov had realized himself through the discovery of Sonya, Svidrigailov, and Dunya. The character finds an analogy of his soul in the souls of other characters (Merezhkovskii, 1995).

The ability of Dostoevsky to depict the surrounding life deeply interested N.A. Berdyaev (1994) and V.I. Ivanov (1990). Russian philosophy of the turn of the century was close to the idea that knowledge of the outside world is possible through deep, inner, spiritual knowledge. In "Three Speeches in Memory of Dostoevsky", Vladimir Solovev (1988) identified two leading contradictions that characterized his characters: the first is the contradiction between the character's soul and the environment, and the second is the contradiction between the character's state of mind and the nature of the human soul. That is, on the one hand, the character is in a certain rift, a certain conflict with other people, the state of public opinion, collective or common ideas and, on the other hand, they feel the wrongness of their spiritual impulses regarding the truth that the human spirit sees as the first and main one. These two types of contradictions permeate the work of Dostoevsky, but he focuses primarily (and this amounts to his strength and originality as an artist) on the second, internal contradiction.

$\mathrm{N}$. Berdyaev noted that the theme of freedom was the leading theme in the work of Dostoevsky. It reflects the paradox, the tragedy of human freedom. Dostoevsky depicts his characters striving for freedom, and in this desire, they are ready to do anything. Dostoevsky's freedom is the freedom of evil as much as freedom of good. This rebellion against this universal category, against the world order in general, characterizes the characters of Dostoevsky, such as Raskolnikov, Ivan Karamazov, Stavrogin. The characters Dostoevsky, according to N. Berdyaev, rebel against the necessity, against the universal laws of history, against the divine Predestination. This is a metaphysical rebellion, which is a search for new freedom, not constrained by rational frameworks. However, such freedom is ultimately directed against the person themselves and is completed by its last feature, the crime - the denial of the character's own life and other people's lives, i.e. any unlimited freedom (arbitrariness) inevitably comes to its denial, to absolute necessity and violence over the freedom of other people (Berdyaev, 1990).

The attitude towards Dostoevsky in the 19th and early 2oth centuries basically "comes down to the fact that Dostoevsky is great only as a humanist (or mystic, or prophet), but not as an artist" 
(Ivanova, 1995, p. 127). However, as the researcher of the writer D.F Wallace (2005) correctly noted, the significance of Dostoevsky is that he destroyed the established canons and even stepped outside the boundaries of art.

Today, the work of the following researchers, in particular, A.P. Belik (1974), N.F. Belchikov (1971), L.P. Grossman (1962), A.S. Dolinin (1989), V.Ya. Kirpotin (1980), G.M. Fridlender (1985), is of interest due to the researchers' versatile approach to the writer.

At the beginning of the 21st century, the works of Dostoevsky continue to evoke keen interest, arouse strong emotions, and prompt readers to deep thoughts. Here are just some of the studies of Dostoevsky's work that appeared in print at the beginning of the 21st century: books by such authors as V. Kantor (2010), J. Scanlan (2006), R. Lauth (1996), S.M. Capilupi (2013), R.L. Jackson (1996), Kaye (1999), K. Lantz (2004). It is characteristic that all these researchers, as a rule, try to consider the themes and ideas of Dostoevsky's works in the context of modern anthropological and socio-cultural problems. In this case, sometimes researchers discover contexts that are quite unexpected at the first sight. For example, the figure of an "underground man" is updated in connection with the sensational film "The Matrix" (Hibbs, 2005), the relationship between some of Dostoevsky's characters with Nietzsche's philosophy (Jensen, 2018) is pointed out, and some scholars review the psychographic aspects of the writer's work (Romanova, 2019) or clarify the relationship between reason and faith (Kasatkina, 2015).

In the last decades, problems associated with national identity in the work of Dostoevsky have been of particular interest to scholars in various fields of the humanities (Volkova, 2017; Kasavina, 2016) This interest is largely conditioned by the search in modern society for criteria of ethnic identity, the development of a national development strategy, a complex social atmosphere in which hypertrophic manifestations of the national phenomenon are possible. Dostoevsky in this context is perceived as a writer who posed these problems extremely deeply and, at the same time, is extremely ambiguous. The set of ideas put forward by the writer at one time, connected with the ideology of the so-called Pochvennichestvo (a patriotic movement inspired by the "native soil") in its bud contained deep contradictions, which are also pointed out by modern researchers (Saraskina, 2008).

The noted complexity of Dostoevsky's vision of the problems of national existence explains the desire of scholars to comprehend it in many aspects, from the historical, philosophical, cultural, and aesthetic perspectives. Among literary works related to this problem, we would like to highlight the studies of recent decades devoted to Pochvennichestvo (De Lazari, 2004; Dubovitskaya, 2013), as well as works affecting a wider range of national and religious problems in the works of Dostoevsky (Kasatkina, 2003; Krysin, 2008; Zastrozhnova, 2004). They emphasize that the contradictions of the Pochvennik ideology relate to the fundamental contradictions of the entire legacy of Dostoevsky, have a deep connection with the philosophical and anthropological paradigm of the writer, and lead to its archaic and mythological foundations. At the same time, the literary perspective of considering the Russian paradigm in the writer's works remains on the periphery of the modern study of the work of Dostoevsky, since the ethnological aspects of these problems are not important for the authors of the mentioned works.

The name of Dostoevsky, as a victim of tsarist arbitrariness, was in the blaze of glory of a genius and a martyr. Events and situations seem to have "provoked" him to reflection, suffering, global conclusions and discoveries about life and the human being. "Dostoevsky," notes Yu. Seleznev, "built his spiritual world in completely abnormal, boundary conditions, on the verge of life and death, both physical and spiritual" (Seleznev, 1981, p. 55). 
Z.B. Andersen (2000) notes that Dostoevsky, as a writer, applies the phenomenological method when he analyzes life experience in all its manifestations - what and how one lives and feels, that is, their feelings and experiences as they appear to them. From the depths of this experience, he explores who we are and what our feelings-and feelings can say about our Self, our separation, or connection with the world and other Self. Therefore, the researcher believes, the spiritual searches of Dostoevsky, who, deny both individualism and collectivism, intuitively felt the path to collegiality, to such cohabitation in which individuals achieve full disclosure and determination of their unique, unique and original essence.

P.N. Markes (2020) explores the work of Dostoevsky from the behavior of Russian people in borderline situations that create the framework of the inner spiritual life and practical activities of man, as it were from the "framework" of existence, beyond which "non-existence" extends. Dostoevsky had to go through the "experience of the end", to go through a borderline situation the years of penal servitude, years of heavy loneliness, painful thoughts and difficult decisions (the people closest to him died at that time). In those most difficult years for himself, the researcher notes, Dostoevsky wrote Crime and Punishment, where all the characters are people who have reached their limit and found themselves in borderline existence, and the main theme of the novel is a desperate person who is ready for anything and detached from everything.

Researchers drew attention to the absence of comprehensive details of the outside world, in particular the landscape, in the works of Dostoevsky. The writer is primarily interested in anthropological issues. R. Feuer Miller wrote about this: "It is important to find a person without other relatives in life, besides their kind: only the human race is related to it, and not nature, and therefore it has a mono theme: the human being and the fate of humanity" (Miller, 2007, p. 38).

F.V. Makarichev notes that "today the circle of supporters is gaining the thesis of anthropocentric and moral, existential coordinate systems of the spiritual world created by Dostoevsky" (Makarichev, 2010, p. 17). V.A. Koltsova agrees with him; according to her, all the work of Dostoevsky is fundamentally human-centered: there are practically no surrounding events, specific political situations, details of official actions and situations, detailed descriptions of social processes in his works. Everything is focused on the human being, and it is not so much about any specific people, but about human nature and essence. As a result, the characters of Dostoevsky are often deprived of clear social specifics, although they do take part in situations of human life. Most likely, they demonstrate humanity as such, that is, that which is inherent in man in general (Koltsova \& Kholondovich, 2013).

I.N. Ivanova compares the inner world of the characters of Dostoevsky to the characters of postmodern prose. In her opinion, it would be most appropriate to compare the characters of Dostoevsky with the characters of Russian postmodern literature, in particular V. Pelevin. The researcher believes that the inner world of their characters in both cases has a certain division into two spaces where the characters live: the spiritual and the material. These two spaces are equally rich, and the spiritual life even rises above the material existence. Besides, in the novels of both authors, the material, the real world is perceived following the spiritual, inner world, and through its prism. That is, the characters live, so to speak, completely within themselves, and they look at the other phenomena as opposed to them through the inner window. Moreover, in both Pelevin's and Dostoevsky's works, the main character seeks the answer to an internal question within themselves, and this answer should be a way out of the internal conflict situation, and also leads the character to certain internal freedom, inner peace. A common feature is also the emphasis on the secondary nature of how the outside world will react to the result of such an achievement of freedom. From the position of the material, the external world, the actions of the characters are 
incomprehensible and often perceived without understanding, or sometimes even with hostility or neglect. However, the role of the inner world is so great and vast that the rest does not matter. A common feature for the novels by Pelevin and Dostoevsky is the theme of loneliness. The character is constantly alone and cannot find true understanding, but what the character perceives as understanding is constantly something else (Ivanova, 2018).

According to L. Bagby (2016), the perceptions, existential and rational pictures of Dostoevsky's artistic worlds are rooted in the genetic roots and formulas of the existence of his human phenomenon found by spiritual experience. W.S. Brumfield (2000) writes about the $a$ priori inclinations of the human soul in the work of Dostoevsky. In his opinion, the natural tendency towards rebellion inherent in Russian people is the reason for their life unhappiness as a whole.

I. Volgin believes that there are moments in Dostoevsky's behavior that can be described as structural: "they follow from the general mental structure of his personality" (Volgin, 1986, p. 76). Here we can talk about the peculiarities of the Russian mentality, compassion, growing into "sympathy". The researcher defines this trait as a purely Russian attribute: "Dostoevsky is the Russian origin, the suffering, many-sinful, many-thoughtful and difficult one" (Moskovtseva, 2005, p. 77).

Z.Y. Moskovtseva (2005) believes that the artistic system of the works of Dostoevsky, in particular its person sphere, is revealed in the context of the Pochvennik idea (the "Russian idea") of the writer when depicting a Russian person; it is determined by his "anthropological existentialism", which implicitly includes several archaic and mythological oppositions (first of all, "ours vs. alien") and a specific understanding of such categories as "nature" and "living life". The artist's literary imbalance is characterized by a distinction between the aesthetic (mainly artistic, poetical, and stylistic) and journalistic (non-literary, even "every day") vectors of image and interpretation of Dostoevsky as representatives of the Russian nation and national stereotypes.

At the same time, any attempt to interpret Dostoevsky thematically leads to an artificial narrowing. Even the transfusion of the same illustrative quotes from one research text to another does not confirm the truth of those statements. Besides, it is practically impossible to verify the truth of any individual of those statements, without relying on the material of the full corpus of the writer's heritage. None of the research topics mentioned, semantically stratified, gives rise to serious objections. This is seen as the merit of Dostoevsky himself, who, as a charismatic author, knows how to direct the thought process of the vast majority of recipients, including professional researchers, correctly.

\section{Methods}

The purpose of the study is to identify the originality and ideological as well as functional status of the ethnomental component in the works of Dostoevsky.

To achieve this goal, we need to solve the following problems:

- to determine the origins of Russian ethnos in the work of Dostoevsky based on the analysis of life facts, deeds, spiritual searches Dostoevsky;

- based on the general anthropological attitude of the writer and his support on the "nature" of the human being, to identify and analyze ethnic elements in the work of Dostoevsky.

The subject of the study is the ethnomental component in the works of Dostoevsky.

The object of study is the artistic and journalistic works of Dostoevsky. 
The theoretical and methodological concept of the study is based on the idea of relative autonomy (immanence) of a literary work and artistic image, their indirect connection with the ideological principles of the writer. In the formation of methodological guidelines to identify the ethnic component in the writer's fiction and journalistic works, a significant role was played by the concept of M. Bakhtin on the polyphonic nature of Dostoevsky. It emphasized the non-equality of the "artistic" and "journalistic" statements of the writer and emphasized the impossibility of understanding the author's position from any character of the work. The works on the theory of literature, studies of national and ethnic problems in modern humanitarian studies, works devoted to the work of Dostoevsky were also of great importance for the study.

The tasks and the indicated object and subject of research required a combination of classical and modern methods of analysis.

The work implements both general methods of scientific research (analysis, synthesis, description, definition, interpretation), and proper literary studies; an integrated complex of approaches and methods, the ideas and principles of the traditional cultural and historical method, which provides the general cultural, sociological, psychological aspects of the study of the literary heritage of Dostoevsky.

The cultural and historical method was chosen as the main one, and it contributed to the study and disclosure of the features of ethnomental components in connection with the historical and cultural circumstances in Russia at the end of the 19th century.

The typological method contributed to the literary clarification of the ethnomental components in fiction and journalism of the writer. The narratological approach to the works of Dostoevsky was used to analyze their narrative structure, the correlation of author and other people's speech, to identify different points of view on the problem and to establish the ambiguity of the author's position. The contextual analysis allowed us to analyze the images of the characters, first, within the local context (which is especially important if certain characteristics of the characters are indicated by the categorical manner and bias on the part of the narrator or character); second, within the macrocontext, which includes other literary sources, in particular the journalism of the writer and his letters, which makes it possible to make for appropriate comparisons and build a verification model of the study.

The biographical method was used to characterize the writer's biography in conjunction with creativity, to establish the defining links between the biography of the author and the artistic reality. The comparative historical method helped to determine the typical and distinctive features of the writer's creative heritage in the context of the era. Psychological made it possible to clarify the influence of the psychic characteristics of the writer as a factor influencing the specifics of creativity. The analytical and descriptive method was used in the work for the selection, systematization, description, and analysis of the multiple structurally meaningful characteristics of works.

The study used elements of structural analysis (for the analysis of works from the relationship of parts and the whole, form and content), intertextual analysis (to identify the relationship of the works of Dostoevsky with texts of other authors at the level of ideas, style features, etc.).

\section{Results}


In general, many mental, ideological, and even linguistic "Russian elements" can be found in the texts of Dostoevsky. Let us review some of them.

Tragic attitude and compassion. The aesthetics of the tragedy is inherent in the writer's work. The tragedy permeates all layers of works: from the plot, the images of ideas to the worldview, philosophy. The tragedy is present in the fate, feelings, the whole existence of the characters. The author's attitude towards the world, the human being, human existence is tragic. This tragic essence is not specifically historical or individual, but such that is inherent in existence and the world as a whole. This kind of attitude is characteristic of the Russian mentality: "it is universally recognized," notes E.I. Zinoviev, - that from time immemorial the Russian people have had an extremely high sense of tragedy. Christianity pushed towards this, as it allowed our ancestors to understand the uniqueness and intrinsic value of human life. Therefore, suffering was accepted with pain and regret, and death as the greatest tragedy" (Zinoveva, 2010, p. 32).

In the works of Dostoevsky, there is no optimistic author's knowledge of how to avoid the pain and darkness of life. Something inevitable and terrible does not pursue from the outside but always exists in the core of the human being. Such intrinsic features are pain and tragedy, restlessness and the abyss of darkness of Stavrogin, Raskolnikov, Marmeladov, and other characters of Dostoevsky. Recall the famous Marmeladov's line "my trait had come out". This "trait" cannot be explained socially, morally, or mentally. This is something inherent, inevitable, the nature of the character's soul. This is the mystery that he carries in his soul and sometimes he cannot comprehend it, he doesn't know what to do with himself or with his nature. Hence the law is not to condemn, but to sympathize, and in the end on the day of judgment to understand and forgive: "And He will hold out His hands to us and we shall fall down before him... and we shall weep... and we shall understand all things! And everyone will understand" (Dostoevsky, 2008).

As the highest moment of human coexistence, Dostoevsky proclaims sympathy and selfsacrifice, makes the reader see a person and have pity on them, feel their pain even when they are below the line of social norms.

Dostoevsky proclaims sympathy as the most important feature in human existence: "Compassion is the chief, and, maybe the only law of human existence". He reveals the person inside the person through compassion. However, note that this approach concerning the world and the human being, namely love and compassion, is characteristic of the Russian attitude, the Russian ethnomentality.

Dostoevsky discovers the world through intuition, feelings, the superiority of the spiritual, irrational over the logical and rational. Dostoevsky is characterized by a purely Russian worldview, ways of understanding the world, and elements of his artistic world. Besides, the writer does not associate evil with society. First of all, for Dostoevsky evil and good are the choice of the heart, conscience, the moral choice of the human being.

Ethnic Russian mythologemes. The phenomenological manifestations of the supernatural in the personality of the character in the works of Dostoevsky often correspond to the reconstruction of the mythologeme of the devil in the Russian tradition. The devil comes to Ivan Karamazov, seduces Raskolnikov, and makes him kill, drives Stavrogin crazy, etc. The presence of a trait as part of the world is characteristic of the Russian worldview. The ego-consciousness of the characters cognizes and realizes itself through the Shadow (C.G. Jung). The coexistence of characters with their shadowy archetypal essence in Dostoevsky's works leads to disaster, such as madness, suicide, death. Infernality is inherent in almost all the images of Russian writers, even female ones. The feeling of the presence of darkness in its essence, its soul makes the characters of Dostoevsky experience all 
the possible abysses of this darkness, this unknown demonic in itself. The beast sits in everyone, it makes the consciousness shaky ("Notes from Underground"), erases the line of the moral and the criminal (Raskolnikov, Svidrigailov from "Crime and Punishment", the Karamazov brothers from the novel of the same name, Rogozhin from "The Idiot", etc.), distorts the nature of the bright and spiritual, tempts and kills (Nastasya Filippovna from "The Idiot"). God and Satan, good and evil, light and darkness permeate the nature of texts and the nature of the world in texts, which testifies to the author's worldview, his philosophy of life, and the human being.

In the works of Dostoevsky, there is a dialogue between the celestial sphere and the underworld. Human nature is at a turning point, the boundary of two worlds, the Earth and Heaven. In the soul, there is a struggle between good and evil, God and Satan (Valeeva, 2017). The human being is the center of the universe, the microcosm, and from there comes their duality. Inside a person, there is a continuous struggle of opinions, aspirations, passions, which can either absorb them or help restore the broken integrity of nature. Irrational vital forces, devoid of a guide to values, destroy the person's personality, their self, because every action is related to the implementation of good or evil, being at the same time a choice of being or non-being.

Dostoevsky's world, events, the human and their life are the result of the eternal resistance of these two principles, which intensifies conflicts, makes them content on a global scale and cosmic force. Such a worldview has been ethnically inherent in Russians since pagan times.

The archetype of the feminine in human nature. The male and female in the work of the writer are delineated and do not merge into one harmonious world order. Perhaps this is not only a philosophical and worldview concept but also a personal, vital one.

The main female images of Dostoevsky's works are overwhelmingly emotional, mentally and psychologically divided, wounded by some kind of internal rather than external factors, fatally doomed to mental ordeal and sacrifice. In the context of the works, they more often represent a landmark of moral and Christian light and beauty, a certain refinement, but doomed to suffering and wandering. Such are the images of Nastasya Filippovna and Aglaya in "The Idiot", of Grushenka and Ekaterina Ivanovna in The Brothers Karamazov, of Sonya Marmeladova in Crime and Punishment. In the universe of Dostoevsky, harmony between the masculine and the feminine is impossible; it is an eternal conflict, a mismatch. Love cannot be "realized", it is broken by the outside world or the painful soul of the character.

Anthropocentricity and existentialism of the fictional world. The center of the fictional world of Dostoevsky is the human being, their spiritual and moral choice in search of true being in borderline situations, at the break of life events. At the same time, they study personalities of the unusual, extraordinary, who do not live like everyone else, who seek the truth, strive for something extreme, the highest in their existence.

Dostoevsky put the human being in the center of the universe, culture, nature, and life in all its manifestations. He puts the human being at the extreme, highest, most significant points of their existence, or the so-called existential "borderline situations", which forces them to choose between good and evil. Dostoevsky makes the moral choice immanent in the essence of the human being.

In other words, the doctrine of the human being, anthropology, the metaphysics of the human being, or, as Nikolai Berdyaev aptly put it, "the experimental metaphysics of human nature" is the subject of Dostoevsky's basic life and creative aspirations. For a Russian novelist, the human being makes up the basis, center, core of any reasoning, then the initial field of meanings from which any philosophical discussion should proceed and develop. According to Berdyaev, "Dostoevsky is primarily a great anthropologist, a researcher of human nature, its depths and its 
secrets. All his work is anthropological experiments and experiments" (Berdyaev, 1990, p. 85). In this regard, the evidence of Nikolai Strakhov, a tireless assistant and first biographer of Dostoevsky, seems very indicative. In his memoirs, he notes this detail: it turns out, during the writer's travels to foreign countries, he was "not much interested by nature, or historical monuments, or works of art [...]. All his attention was directed to people, and he grasped only their nature and characters" (Berdyaev, 1990, p. 91).

Such an approach in the art and the fictional world of the author is not rational, but rather irrational; it is a kind of artistic development of the human world through the heart and conscience, a purely Russian mental way of feeling and artistically creating the world. However, Dostoevsky goes further, going beyond the character, the psychology of the human being. His manifestation of the person on the verge is a manifestation of something universal, secret, that comes from the very fundamental principle of the world, from light and darkness, from good and evil in their absolute, from God and the devil.

At the same time, it is important to clarify that Dostoevsky was not only interested in anthropological issues. In his works, he invariably started from the real spiritual situation of the individual and carefully studied it, but in the end, as already emphasized, he appealed to Christianity, which, however, was already experiencing a serious crisis in Europe, and therefore the writer's position on Christian values acquired a "rehabilitation" nature (as was the case with such thinkers of Romanticism as Friedrich Schleiermacher, Novalis, Rene Chateaubriand, and others). Dostoevsky existentially interpreted anthropological questions, focusing on the problems that arise in the context of events that determine human life as a whole, events that are usually not just important, but dramatic and even tragic (Vyacheslav Ivanov described Dostoevsky's novel as "a tragedy novel"). These problems of suffering, fear, death, guilt, concern mainly the crisis, necessary, boundary moments in the constitution of a person. When it comes to the existential dimension, within its framework, as can be seen from the above, negativist existences prevail, although, of course, they emerge in the light of such "neutral" problems as the problems of faith, immortality, conscience, responsibility, choice, freedom, the meaning of human existence. Thus, through the negativist dialectics of human existence, the indicated questions arise in the maximum acuteness and drama, and one of the radical conclusions reached by the characters of Dostoevsky is the statement about the danger of anthropophagy.

As already noted, the author does not consider a person either as a social or political being. However, the external side of the person is not enough for him; he reveals "the person inside the person". M. Bakhtin speaks of a fundamentally new form of artistic vision of the human being. Already in his first work, "Poor Folk", Dostoevsky renounces Gogol's ideas about the "little man", portrays a small revolt of the character himself against his full definition of literary, social, and psychological in the image of Akaky Akakievich. He goes further and deeper into the nature of the human being. The subject of his studies of man is depth, the abyss of possible Good and Evil, conflicts of light and darkness, God and the devil in the heart of the human being. The writer asserts that it is impossible to turn a living person into an object of a final definition behind their back (Bakhtin, 1963), that incompleteness always remains in a person. A person never coincides with themselves. According to Dostoevsky, the true life of an individual occurs at the point of this discrepancy between a person and their self, at the point of going beyond the limits that determined it, reduced it to a certain formula. Hence the polyphony of his novels, where there are no conclusions about characters who, as long as they are alive, can constantly change. One must admit that there was nothing similar in Russian literature before Dostoevsky. However, the path of cognition, and the artistic image of the human being, their existence through the heart, feelings 
uncharacteristic of Russian literature. Thus, having purely Russian, national research material (the Russian soul) Dostoevsky comprehends it in the same mental Russian way, with his heart.

\section{Discussion}

In the conclusion of the study, we dwell on the origins of Russian ethnos in the work of Dostoevsky. The writer's grandfather, Andrei, served as an Orthodox priest in the village of Voitovtsy in Podolia in 1782-1820. The father of the writer was also preparing for the career of a priest. Besides, the priests at that time were the guardians of the cultural traditions of the Orthodox population, its spiritual heritage. Although father Dostoevsky moved to Moscow, he had grown up in the bosom of the traditional culture of the Orthodox clergy, which could not but affect the religiosity and worldview of his son. The mother taught her son to read and write on the collections of stories of the Old and New Testaments. The story of Job was especially interesting and shocking for the future writer. Later in 1875 , Dostoevsky wrote to his wife:

"I read the book of Job, and she brings me painful delight. This book, Anya, this is strange, is one of the first that struck me in my life, I was still a baby then!" (Grossman, 1962).

Nevertheless, certain mental and ethnic features of Russian Orthodox culture were "mastered" by Dostoevsky, gave him a deep spiritual component at a subconscious level, and formed a special socio-cultural certainty. First of all, this can be seen in the tragic and painful perception of someone else's "common" pain, a kind of cult of weakness, as obedience to fate and fidelity to God's providence. Just these features of the work of Dostoevsky captured Belinsky and Nekrasov ("New Gogol was born!").

The further fate of the brilliant artist also affects the artistic and philosophical paradigms of texts. Let us review some of them. Despite belonging to a certain socio-cultural group, the writer at the same time was a socially ambivalent, marginal figure. Dostoevsky was a typical commoner by origin, but was not accepted among the commoners or the nobility: "he changed states, passed from one to another, and in this regard, the plans that coexisted in objective social life were stages of his life the path and its spiritual formation" (Bakhtin, 1963, p. 34).

Dostoevsky does not share the advanced views of his social environment, he is opposed to all social circles, remaining lonely, incomprehensible:

"He is a stranger among his people: he is a white crow among famous writers, liberal professors, and talented lawyers. He does not fit into the picture of spiritual contentment and prosperity: there goes "a man of extremes," from the second world altogether" (Volgin, 1991).

The characters of his works are the same representatives of the "random tribe" (Bakhtin, 1963). The break with Belinsky was the first to show the originality of the writer's views, his sociality. Objective circumstances and special giftedness allowed the writer to hear and understand the voices of all social conditions immediately and simultaneously. The position of the commoner and social wanderer, the deepest biographical and internal involvement of the objective diversity of life, all this became the basis of the polyphonic novel. Neither Tolstoy nor Turgenev could afford even in behavior and manners: "Just both writers knew their social rolls, as they say now" (Bakhtin, 1963).

Excessive attention to creativity is not yet a sign of closeness in relations with others for Dostoevsky. Even fame does not make him less lonely: "Do you think I have friends? Have I ever 
had any? " - writes Dostoevsky with bitterness to V. Solovyov, — "Besides the smallest number of people who, maybe, are a little fond of me, I have never had friends" (Dostoevsky, 1996, p. 212).

The fate of Dostoevsky radically changes his life and, at the same time, becomes a deep shock and revelation: in 1849, in connection with the Petrashevsky case, he was first sentenced to death, which was later replaced by hard labor. Ironically, on the eve of his arrest, Dostoevsky took part in the discussion of the activities of the new group, which separated from the Petrashevsky circle. By 1849, Dostoevsky was already known as the author of Poor Folks, but at the same time at odds with Belinsky due to the latter's misunderstanding of The Double. Belinsky, who advocates national social problems, does not accept the abstract humanism of The Double. Again, fate seemed to "help" the author to find his theme, his destiny in literature because of suffering. First, the eerie expectation of the death penalty and then four years of hard labor make the writer radically change his view of the people, his psychology and finally determine his mission, his way in literature. The terrible experience of a prisoner on a death row in a few minutes turns the mind of Dostoevsky upside down. Having already gone beyond the bounds of life, he understands the whole value of the latter:

"As I look back at the past and think about how much time I wasted, how much time was lost in delusions, in error, in idleness, in the inability to live; just as I did not cherish it, how many times I have sinned against my heart and spirit, my heart bleeds. Life is a gift, life is happiness, every minute could be a century of happiness" (Grossman, 1962).

At penal servitude, during doubt and reflection, he acquires a metaphysical understanding of the world and the human being: "No, the human is not simple, there are such abysses in them, such secrets that our sages do not know" (Seleznev, 1981). Besides, the realization that life is everywhere: here, in penal servitude, and that people are everywhere, and nothing human is alien even to criminals. These ideas come as a revelation, after which it is impossible to live as before, and it is already impossible to go astray.

Thus, the writer through suffering receives the grace of truth and affirms his life and creative path, his destiny. He receives a test from the fate that radically divides his life into "before" and "after". The writer reveals the truth of his existence and the existence of the human being in the world of suffering and trials. Perhaps the secret of human existence is hidden here, the thought of the selectivity of the afflicted, which is revealed more, is given more. However, it is indisputable that Dostoevsky, who had been destroyed morally, deleted from public and cultural life for several years, deprived of hope and even the slightest sympathy from the official authorities, not only retained his humanity, morality but also performed a spiritual feat renouncing his aspirations and focusing on the fate of the Motherland, the search for truth, the study of the human being. Is it possible to humiliate a person who is dissolved in the fate of others? Perhaps this is where the gift of prophecy comes from, for the personal is less exciting than the truth. The internal choice of sacrifice is again a priority of the Russian Orthodox mentality.

These features of psychology, worldview, thinking, life and ideological choice of the writer, the way of his existence, are, to a certain extent, a manifestation of mentality. The value system of certain people is implemented in specific individuals, hence the sources of moral choice, internal intellectual decisions. Thus, the basics of Russian mentality are identically manifested in the life and work of the writer.

The social ideas of the late period of Dostoevsky's works belonged to the movement of Pochvennichestvo, the moderate wing of Slavophilia (De Lazari, 2004; Dubovitskaya, 2013). Pochvennichestvo was formed in early186os in the circle of the brothers Fyodor and Mikhail Dostoevsky as a worldview and social ideology opposed to the unproductive confrontation between 
the "Slavophiles" and "Westerners" to reconcile them through the idea of returning the educated part of Russian society to "their native soil", that is, to a popular worldview, popular ideals of good, truth, and morality. Trying to eliminate the extremes of Slavophilia and remove from it the stratification of the artificial nation, the Pochvenniks at the same time upheld the idea of the originality of the historical path of Russia, the spiritual priorities of the Russian worldview. They did not accept the Western ideas of a radical revolutionary restructuring of society and the onesidedness of a materialistically utilitarian arrangement of life, but they did not deny the achievements of the West in the development of culture and civilizations and upholding the selfworth of the human, while at the same time seeing a threat to individualism and spirituality in the Western vector of development.

In the 186os, in parallel with the ideas of Pochvennichestvo, Dostoevsky's system of anthroposophical representations fully developed. Its fundamental discovery consists in comprehending the "duality" of human nature. The "Russian messianism" as a component of the writer's Pochvennichestvo and his key anthropological idea of the tragically contradictory human nature and the ultimate goal of the development of humanity as a global general harmony appear in Dostoevsky's works in a complex and contradictory relationship. The ideal of "all-unity" and the role of the "Russian spirit" in achieving this ideal has a hypothetical dimension in the writer's works, they grow out of the "soil" of that world in which the separation into "one's own" and "another's" reaches a dramatic content. At the same time, Dostoevsky was a realist: unlike the romantic idealism of the Slavophiles, he did not gravitate to the idealization of the people. This is evidenced by the numerous descriptions of evil among the people in his literary and journalistic works.

According to the Pochvennik philosopher and literary critic N. Strakhov, it is easier for a person to believe in evil than to live without any faith. This idea will be close to Dostoevsky, who based his vision of the people on the concept of spiritual roots, that is, inextricable unity with faith in God, which in turn ensures relationships in society. In his journalistic articles, he worshiped the truth that the people possessed, points to the religious coloring of his populism.

The center of Dostoevsky's social thought of this period is the belief in the connection of the people with Christ. The writer is convinced that the people know Christ and bear Him in their hearts. In the heart under the external "animal image" there is a hidden image of God. The thinker believes in the existence of knowledge of the heart, which is transmitted from generation to generation and connected to the hearts of people (Volkova, 2017).

The concept of the public good for Dostoevsky does not consist in the exaltation of one Russian people but is the embodiment of all that is true, deep, most essential in people. That is why his opinion is universal for all humankind. A nation is like an individual, unprotected and weak, suffering under the weight of a difficult fate; the people are united with the land on which they were born, and on which they live and work. The thinker urges to restore this lost connection and return to its roots. He raises the question of upbringing, the influence of parents on young people who have grown up in an atmosphere of indifference, or even in aversion to their homeland. Having torn off from the native land and culture and God, the Russian people will not have solid soil under their feet. The symbol of such wandering, according to the writer, is Petersburg, built on drained swamps, the architecture of which is an eclectic combination of Western European styles. Cutting off from the roots is equivalent to losing the orientation point in the world.

However, Dostoevsky finds a way out of the spiritual crisis of the identity of the people in a return to the sources and God. Sin and poverty have not destroyed the true essence of man, a spark hidden in the depths of human nature. Even the last criminal is not able to destroy this spark, the image of God. The world is saturated with God, and man through faith is connected with Him 
through a mystical connection. A nation consists of individuals with their life situations, but at the same time, they are free, able to create themselves through choices and decisions.

The figure of Dostoevsky became an iconic figure of his time, a representative of the spiritual heritage of world literature of the second half of the 19th century, the embodiment of national and universal Christian ideals. His fate testifies to his ideals, characteristic of the Russian mentality (reflection, sensuality, compassion, inner loneliness, sacrifice). It sets a new vector for the development of Russian literature, raises it to a higher ideological and artistic level, gives radically new accents to the world and national problems of philosophy, religion, morality, spiritual search, and human choice, and in a new way defines the essence of the nature of man himself.

The perception of the world, the chosen priorities of the foundations of the spiritual and life forces us to look for their origin both in ethnic sources and in existential, personal ones. Dostoevsky's work powerfully sets the tone for ethnic-Russian reflection and an existential and anthropological study of the Russian mentality, the Russian soul (Spartakian et al., 2019; Shafazhinskaya et al., 2019a). That is why the conclusions and ideals of Dostoevsky are not entirely acceptable for Western European literature. Instead of the ideal in West European literature - a strong character, a victorious, superior in moral and social planes of existence, Dostoevsky creates a radically opposite positive character, and he is weak and sick (Prince Myshkin, "The Idiot").

The study of the Russian soul through the image of Christ, the philosophy of the heart, and love leads the writer to terrible discoveries, prophecies that come true in the 2oth century. Dostoevsky's prophecies speak of personal metamorphoses of the Russian people, which will lead to spiritual blindness and death (Raskolnikov's theory (Crime and Punishment), Stavrogin (Demons), the teachings of Ivan Karamazov, the story of the Grand Inquisitor (The Brothers Karamazov)).

The phenomenon of Dostoevsky is enormous and mysterious. His spiritual discoveries are significant; they not only state the depths of the possibilities of the nature of human existence but also go beyond the horizon of the hidden, dark, sacred. He is a prophet writer, a preacher, the spiritual father of his people, an educator.

\section{Research Limitations and Research Prospects}

The conclusions of the study can serve as the basis for a more accurate idea of the correlation of the writer's worldview and his work. The materials and conclusions of the study can be used in university courses on the history of Russian literature, in special courses and special seminars on the works of Dostoevsky, for term papers, graduation papers, and dissertations. Testing of research materials can take place during participation in national and international scientific conferences. A promising continuation of the study of the ethnic component of the work of Dostoevsky may become an analysis of historical sources (Byzantine, Old Russian) of the great writer's prose.

\section{Acknowledgments}

This study was performed at the SCHOOL OF FOREIGN LANGUAGES AND LITERATURE, SHANDONG UNIVERSITY. 


\section{References}

Andersen, Z.B. (2000). The Concepts of Domination and Powerlessness in F. M. Dostoevsky's 'A Gentle Spirit'. Dostoevsky Studies, 4, 53-60.

Bagby, L. (2016). First Words On Dostoevsky's Introductions. Boston: Academic Studies Press, 198 p.

Bakhtin, M.M. (1963). Problemy poetiki Dostoevskogo [The problems of Dostoevsky's poetics]. Moscow: Khudozhestvennaya literatura, $167 \mathrm{p}$.

Belchikov, N.F. (1971). Dostoevskii v protsesse petrashevtsev [Dostoevsky in the case of the Petrashevsky Circle]. Moscow: Nauka, 294 p.

Belik, A.P. (1974). Khudozhestvennye obrazy F. M. Dostoevskogo. Esteticheskie ocherki [Artistic images of F. M. Dostoevsky. Aesthetic essays]. Moscow: Nauka, 223 p.

Berdyaev, N.A. (1990). Otkrovenie o cheloveke v tvorchestve Dostoevskogo [Revelations on the human being in Dostoevsky's works]. In O Dostoevskom: Tvorchestvo Dostoevskogo v russkoi mysli 1881-1931 godov [On Dostoevsky. Dostoevsky's works in Russian intellectual life between 1881 and 1931]. Moscow: Kniga, 432 p.

Berdyaev, N.A. (1994). Mirosozertsanie Dostoevskogo [Dostoevsky's worldview]. Filosofiya tvorchestva, kultury $i$ iskusstva [The philosophy of creative work, culture and art]. In 2 volumes, vol. 2. Moscow: Iskusstvo, $511 \mathrm{p}$.

Berdyaev, N.A. (1997). Sudba Rossii [The fate of Russia]. Moscow, Eksmo-Press, 735 p.

Brumfield, W.S. (2000). Theresé-philosophe and Dostoevski’s Grand Sinner. Comparative literature, 32(53), 37-49.

Butenko, A.P., \& Kolesnichenko, Yu.V. (2004). Mentalitet rossiyan i evroaziistvo: ikh sushchnost i obshchestvenno-politicheskii smysl [The mindset of Russians and Eurasianism: their essence and socio-political meaning]. Filosofiya i obshchestvovo, 4, 89-106.

Capilupi, S.M. (2013). "Tragicheskii optimizm" khristianstva i problemy spaseniya: F. M. Dostoevskii [The "Tragic optimism" of Christianity and the problem of salvation: F. M. Dostoevsky]. St. Petersburg: Aleteiya, 288 p.

De Lazari, A. (2004). V krugu Fyodora Dostoevskogo. Pochvennichestvo [W kręgu Fiodora Dostojewskiego. Poczwinnictwo]. Translated from Polish. by M. V. Leskinen. Moscow: Nauka, 207 p.

Dolinin, A.S. (1989). Dostoevskii i drugie: Stati i issledovaniya o russkoi klassicheskoi literature [Dostoevsky and others: Articles and studies on Russian classical literature]. Complied by A. Dolinina; preface by V. Tunimanov; notes by M. Bilinkis et al. Leningrad: Khudozh. lit., 48o p.

Dostoevsky, F.M. (1996). Sobranie sochinenii v pyatnadtsati tomakh [Collected works in fifteen volumes]. Volume 15. Pisma. St. Petersburg: Nauka (Leningrad branch), 864 p.

Dostoevsky, F.M. (2008). Prestuplenie i nakazanie [Crime and punishment]. Moscow: AST, AST Moskva; Vladimir: VKT, 608 p.

Dubovitskaya, N.S. (2013). Rol povchennichestva v formirovanii mirovozzreniya F.M. Dostoevskogo [The role of Pochvennichestvo (return to the native soil) in the formation of the worldview F.M. Dostoevsky]. Vestnik Universiteta, 21, 256-259.

Dumnova, E.M. (2013). "Mentalitet" i "mentalnost" kak kategorii sotsialnoi filosofii [Mindset and mentality as categories of social philosophy]. Izvestiya Saratovskogo un-ta. A new series, 13(1), 25-29.

Durkheim, É. (1996). Elementarnye formy religioznoi zhizni [Les Formes élémentaires de la vie religieuse]. Moscow: Izd. dom Delo : RANKhiGS, $310 \mathrm{p}$. 
Eromasova, A.A., \& Kutbiddinova, R.A. (2010). Filosofiya i psikhologiya: rossiiskaya mentalnost: uchebnoe posobie [Philosophy and psychology: the Russian mentality (a manual)]. Yuzhno-Sakhalinsk: SakhGU, $224 \mathrm{p}$.

Fridlender, G.M. (1985). F. M. Dostoevskii i mirovaya literatura [Dostoevsky and the world literature]. Leningrad: Sovetskii pisatel, $456 \mathrm{p}$.

Grossman, L. (1962). Dostoevskii [Dostoevsky]. Moscow: Molodaya gvardiya, 544 p.

Gubanov, N.N. (2014). Formirovanie, razvitie i funktsionirovanie mentaliteta v obshchestve: Monografiya [The formation, development and functioning of mindset within a society: a monograph]. Moscow: Mezhdunarodnyi izdatelskii tsentr Etnosotsium, 214 p.

Hibbs, T. (2005). Zapiski iz podpolya: nigilizm i "Matritsa" [Notes from Underground: Nihilism and The Matrix]. In "Matritsa" kak filosofiya [The Matrix and Philosophy] (pp. 213-228). Translated from English by O. Turukhina. Ekaterinburg: U-Faktoriya.

Ivanov, V.I. (1990). Dostoevskii i roman-tragediya [Dostoevsky and the tragedy novel]//O Dostoevskom. Tvorchestvo Dostoevskogo v russkoi mysli 1881-1931 gg [On Dostoevsky. Dostoevsky's works in Russian intellectual life between 1881 and 1931]. Moscow: Kniga, 432 p.

Ivanova, A.A. (1995). Filosofskie otkrytiya Dostoevskogo: monografiya [Dostoevsky's philosophic discoveries: a monograph]. Moscow: n.p., 194 p.

Ivanova, I.N. (2018). Avtor i personazhi F.M. Dostoevskogo kak subekty dialoga i obekty postmodernistskoi igry v sovremennoi otechestvennoi proze [The author and characters of F.M. Dostoevsky as subjects of dialogue and objects of the postmodern game in modern Russian prose]. Aktualnye problemy filologii i pedagogicheskoi lingvistiki, 2, 160-166.

Jackson, R.L. (1996). Dialogues with Dostoevsky: The Overwhelming Questions. Stanford: Stanford University Press, 256 p.

Jensen, K.A. (2018). Nietzsche and Dostoevsky: on the verge of nihilism. Dostoevsky Journal, 19(1), 85-89.

Kantor, V. (2010). "Sudit Bozhyu tvar". Prorocheskii pafos Dostoevskogo. Ocherki [Judging God's creature. Dostoevsky's prophetic pathos. Essays]. Moscow: ROSSPEN, 422 p.

Karasev, L.V. (1994). O simvolakh Dostoevskogo [On Dostoevsky's symbols]. Voprosy filosofii, 10, 90-111.

Kasatkina, T.A. (2003). Voskreshenie Lazarya: opyt ekzegeticheskogo prochteniya romana F. M. Dostoevskogo "Prestuplenie i nakazanie" [The resurrection of Lazarus: an exegetical reading of F. M. Dostoevsky's novel Crime and Punishment]. Voprosy literatury, 1, 176-208.

Kasatkina, T.A. (2015). Svyashchennoe v povsednevnom: dvusostavnyi obraz v proizvedeniyakh F. M. Dostoevskogo [The sacred in the everyday things: a two-part image in the works of F. M. Dostoevsky]. Moscow: IMLI RAN, 528 p.

Kasavina, N.A. (2016). Grani russkogo samosoznaniya: F.M. Dostoevskii i L.N. Tolstoi [Facets of Russian identity: F.M. Dostoevsky and L.N. Tolstoy].Yaroslavskii pedagogicheskii Vestnik, 4, 189-193.

Kaye, P. (1999). Dostoevsky and English Modernism 1900-1930. Cambridge: Cambridge U.P., 248 p.

Khazankovich, Yu.G. (2019). The mythological discourse of the itelmen poetry (based on the works of G. Porotov). Humanities \& Social Sciences Reviews, 7(6), 841-844.

Kirpotin, V.Ya. (1980). Mir Dostoevskogo [Dostoevsky's world]. Moscow: Sovetskii pisatel, 376 p.

Koltsova, V.A., \& Kholondovich, E.N. (2013). Voploshchenie dukhovnosti v lichnosti i tvorchestve F. M. Dostoevskogo [The embodiment of spirituality in the personality and work of F. M. Dostoevsky]. Moscow: Institut psikhologii RAN, 304 p. 
Krysin, R.I. (2008). Eskhatologicheskaya sistema vzglyadov F. M. Dostoevskogo [The eschatological worldview of F. M. Dostoevsky]. Vestnik Tambovskogo universiteta, 11(67), 254-258.

Kuznetsova, E. V. (2008). Etnicheskaya identichnost lichnosti kak obekt issledovaniya sovremennogo gumanitarnogo znaniya [Ethnic identity of an individual as an object of study in modern humanitarian studies]. Vestnik Nizhegorodskogo universiteta. Seriya Sotsialnye nauki [Series: social studies], 4(12), 121-127.

Lantz, K. (2004). The Dostoevsky Encyclopedia. Greenwood Pub Group Inc,, 536 p.

Lauth, R. (1996). Filosofiya Dostoevskogo v sistematicheskom izlozhenii [Die Philosophie Dostojewskis in systematischer Darstellung]. Moscow: Respublika, 447 p.

Likhachev, D.S. (2004). Razdumya o Rossii [Thoughts about Russia]. 3rd edn. St. Petersburg: Logos, 654 p.

Makarichev, F.V. (2010). Tipologiya geroev F. M. Dostoevskogo: Uchebno-metodicheskoe posobie [Typology of F. M. Dostoevsky's characters: a manual]. Magnitogorsk: Izd-vo MaGU, 39 p.

Markes, P.N. (2020). Psikhologicheskii analiz antipsikhologicheskogo romana: chtenie "Prestupleniya i nakazaniya" Dostoevskogo cherez prizmu psikhoanaliza Vygotskogo [Psychological analysis of an antipsychological novel: reading Dostoevsky's Crime and Punishment through the prism of Vygotsky's psychoanalysis]. Yazyk i tekst, 7(1), 40-48.

Merezhkovskii, D.S. L. (1995). Tolstoi i Dostoevskii: Vechnye sputniki [Tolstoi and Dostoevsky: the eternal companions]. Moscow: Respublika, $623 \mathrm{p}$.

Miller, R.F. (2007). Dostoevsky's Unfinished Journey. New Haven: Yale Univ. Press, 268 p.

Moskovtseva, Zh.Yu. (2005). "Russkaya ideya" vo vzglyadakh pochvennikov: (A.A. Grigorev, M.M. Dostoevskii, F.M. Dostoevskii, N.N. Strakhov) [The "Russian idea" in the views of the Pochvennik writers: (A. A. Grigoriev, M. M. Dostoevsky, F. M. Dostoevsky, N. N. Strakhov)]. In Nauchnye trudy MPGU: sb. st [MPGU research works: a collection of papers] (pp. 107-112). Moscow: Prometei.

Okladnikova, E.A. (2006). Etnosotsiologiya (Teoriya etnicheskikh tsennostei): ucheb. posobie [Ethnosociology: (The theory of ethnic values): a manual]. St. Petersburg: SPbGIEU, $170 \mathrm{p}$.

Ortega y Gasset, J. (1991). Chto takoe filosofiya? [¿Qué es filosofía?]. Moscow, Nauka, 450 p.

Razzhivin, A.I., Donskova, E.S., Pashkurov, A.N., Dulalaeva, I.Yu., \& Pengfei, L. (2019). Transitional era gallantry culture in the focus of intercultural communication problem (on the example of N.M. Karamzin's prose). Humanities \& Social Sciences Reviews, 7(6), 1216-1224.

Rev. Iustin (Popovich). (2007). Filosofiya i religiya F. M. Dostoevskogo [The philosophy and religion of F. M. Dostoevsky]. Minsk: Izd. D. V. Kharchenko, 312 p.

Romanova, E.S. (2019). Psikhograficheskii aspekt tvorchestva F. M. Dostoevskogo [The psychographic aspect of F. M. Dostoevsky's works]. Sistemnaya psikhologiya i sotsiologiya, 1(29), 31-46.

Saraskina, L.I. (2008). "Ya ditya neveriya i somneniya..." : F. M. Dostoevskii i simvol very v russkoi literature XIX veka ["I am a child of unbelief and doubt ...": F. M. Dostoevsky and the creed in Russian literature of the 19th century]. In Rakursy. Issue 7 (pp. 330-355). Moscow: LENAND.

Scanlan, J. (2006). Dostoevskii kak myslitel [Dostoevsky the Thinker]. Translated from English by D. Vasilev, N. Kireeva. St. Petersburg: Akademicheskii proekt, 256 p.

Seleznev, Yu. (1981). Dostoevskii [Dostoevsky]. Ser. "Zhizn zamechatelnykh lyudei" [Series: the life of great people]. Moscow: Molodaya gvardiya, $544 \mathrm{p}$.

Shafazhinskaya, N.E., Kats, M.L., Smirnov, A.V., Ovsyannikova, V.A., \& Kruglova, M.G. (2019a). Integration of traditions in crossover music as a way to bridge the intergenerational gap. Humanities $\mathcal{E}$ Social Sciences Reviews, 7(6), 1230-1234. 
Shafazhinskaya, N.E., Shcherbinina, V.M., Ivanova, E.Yu., Belyakova, T.E., \& Pereverzeva, M.V. (2019b). Learning about world art culture as a method of forming a universal cross-cultural communication competence. Humanities \& Social Sciences Reviews, 7(6), 1225-1229.

Shchennikov, G.K. (2001). Tselostnost F.M. Dostoevskogo [The integrity of F. M. Dostoevsky]. Yekaterinburg: Izd-vo Ural, un-ta, $440 \mathrm{p}$.

Solovev, V.S. (1988). Tri rechi v pamyat Dostoevskogo [Three speeches in Dostoevsky's memory]. Works in 2 volumes. Vol. 2 (pp. 289-323). Moscow: Mysl.

Sontag, S. (2007). Loving Dostoevsky. In At the Same Time: Essays and Speeches (pp. 21-36). London: Penguin.

Spartakian, N.S., Ryabova, I.G., Ivanova, E.U., Dugalich, N.M., \& Ermoshin, Yu.A. (2019). A study of the moral-ethical views of mohandas karamchand (mahatma) gandhi under the influence of l.n. tolstoy's nonresistance-to-evil philosophy. European Journal of Science and Theology, 15(2), 171-178.

Valeeva, G.V. (2017). Problema dobra i zla v tvorchestve F.M. Dostoevskogo [The problem of good and evil in the works of F.M. Dostoevsky]. Gumanitarnye vedomosti TGPU, 3(23), 49-54.

Volgin, I.L. (1986). Poslednii god Dostoevskogo [Dostoevsky's last year]. Moscow: Sovetskii pisatel, 576 p.

Volgin, I.L. (1991). Roditsya v Rossii. Dostoevskii i sovremenniki: zhizn v dokumentakh [Dostoevsky and his contemporaries: a life in documents]. Moscow: Kniga, 607 p.

Volkova, E.A. (2017). Religioznye i istoricheskie vozzreniya F. M. Dostoevskogo [Religious and historical views of F. M. Dostoevsky]. Voronezh: VG, $330 \mathrm{p}$.

Wallace, D.F. (2005). Joseph Frank's Dostoevsky. In Consider the Lobster and Other Essays by D. F. Wallance (pp. 255-274). New York: Little, Brown and Company.

Wang, X. (2018). Interpretations of Fyodor Dostoevsky's "The Idiot" by Akira Kurosawa and Andrzej Wajda: A comparative analysis. Vestnik of Saint Petersburg University. Asian and African Studies, 10(2), 159175 .

Zastrozhnova, E.M. (2004). "Malenkii chelovek" v svete khristianskoi traditsii (ot Gogolya k Dostoevskomu) [The "Little man" in the light of Christian tradition (from Gogol to Dostoevsky)]. Moscow: TEIS, 240 p.

Zinoveva, E.I. (2010). Russkaya mentalnost $v$ zerkale yazyka: uchebnoe posobie [Russian mentality in the mirror of the language: a manual]. St. Petersburg: Izd-vo Nestor-Istoriya, 96 p. 